\title{
Performance evaluation of soil moisture sensor in black soil for effective water management
}

\author{
P. R. PATIL, K. NAGARAJAN, S. V. KOTTISWARAN AND K. ARULMOZHISELVAN
}

Received : 27.01.2017; Revised : 10.04.2017; Accepted : 22.04 .2017

MEMBERS OF RESEARCH FORUM:

Corresponding author :

P.R. PATIL, Department of Soil and Water Engineering, Tamil Nadu Agricultural University, COIMBATORE (T. N.) (INDIA)

Co-authors :

K. NAGARAJAN AND $S$. V. KOTTISWARAN, Department of Soil and Water Engineering, Tamil Nadu Agricultural University, COIMBATORE (T. N.) (INDIA)

\section{K. ARULMOZHISELVAN,} Department of Agricultural Chemistry and Soil Science, Tamil Nadu Agricultural University, COIMBATORE (T. N.) (INDIA)

\section{Summary}

A study was conducted to develop the sensor and evaluate the soil moisture by using soil moisture sensors and to establish the relationships between soil moisture content and electrical resistance value. Study involved the fabrication of the soil moisture probes, automation network and laboratory testing of automation system. The soil moisture sensor and automation system used for experiment were developed at Department of Soil and Water Engineering, Tamil Nadu Agricultural University, Coimbatore. System is tested and calibrated for automatic irrigation scheduling. Laboratory test programmes were conducted for the performance of the soil moisture sensor in salt solution and different soils and to develop the calibration curve. It was observed that a significant logarithmic relation between electrical conductivity and resistive value of sensor- 1 , sensor-2, sensor-3 and sensor- 4 with an $\mathrm{R}^{2}$ value of $0.95,0.96,0.96$ and 0.96 , respectively and with mean values of electrical resistance found $\mathrm{R}^{2}$ value of 0.964 Because of the sensors were tested for wide range of electrical conductivities ranges 0.01 $\mathrm{dSm}^{-1}$ to $8.12 \mathrm{dSm}^{-1}$. Soil moisture sensor was evaluated with respect to the moisture content of the black soil and it was predicted that the electrical resistance in the range $197 \mathrm{Ohms}$ to $260 \mathrm{Ohms}$ at an average of $224 \mathrm{Ohms}$ at average soil moisture content 58.51 per cent. And at the range of $410 \mathrm{Ohms}$ to $511 \mathrm{Ohms}$ at an average $468 \mathrm{Ohms}$ at 32.41 per cent on 75 hours during the experiment. It was observed that average moisture content 58.51, 57.01, 55.08, $52.73,50.63,48.48,46.16,42.01,39.68,37.26,34.73$ and 32.41 per cent recorded at an average duration of $0,3,6,18,24,27,45,48,51,69,72$ and 75 hours, respectively.

Key words : Soil moisture sensor, Black soil, Field capacity, Resistivity, Electrical conductivity

How to cite this article : Patil, P.R., Nagarajan, K., Kottiswaran, S.V. and Arulmozhiselvan, K. (2017). Performance evaluation of soil moisture sensor in black soil for effective water management. Asian J. Soil Sci., 12 (1) : 49-54 : DOI : 10.15740/HAS/AJSS/12.1/49-54. 